\title{
Teaching NeuroImages: Isolated and persistent hiccup by tiny ischemia at dorsolateral medulla
}

Jung Hwa Seo, MD, PhD

Neurology ${ }^{\circledR}$ 2019;93:e934. doi:10.1212/WNL.0000000000008008

Correspondence

Dr. Seo

jhseo34@gmail.com

Figure Imaging

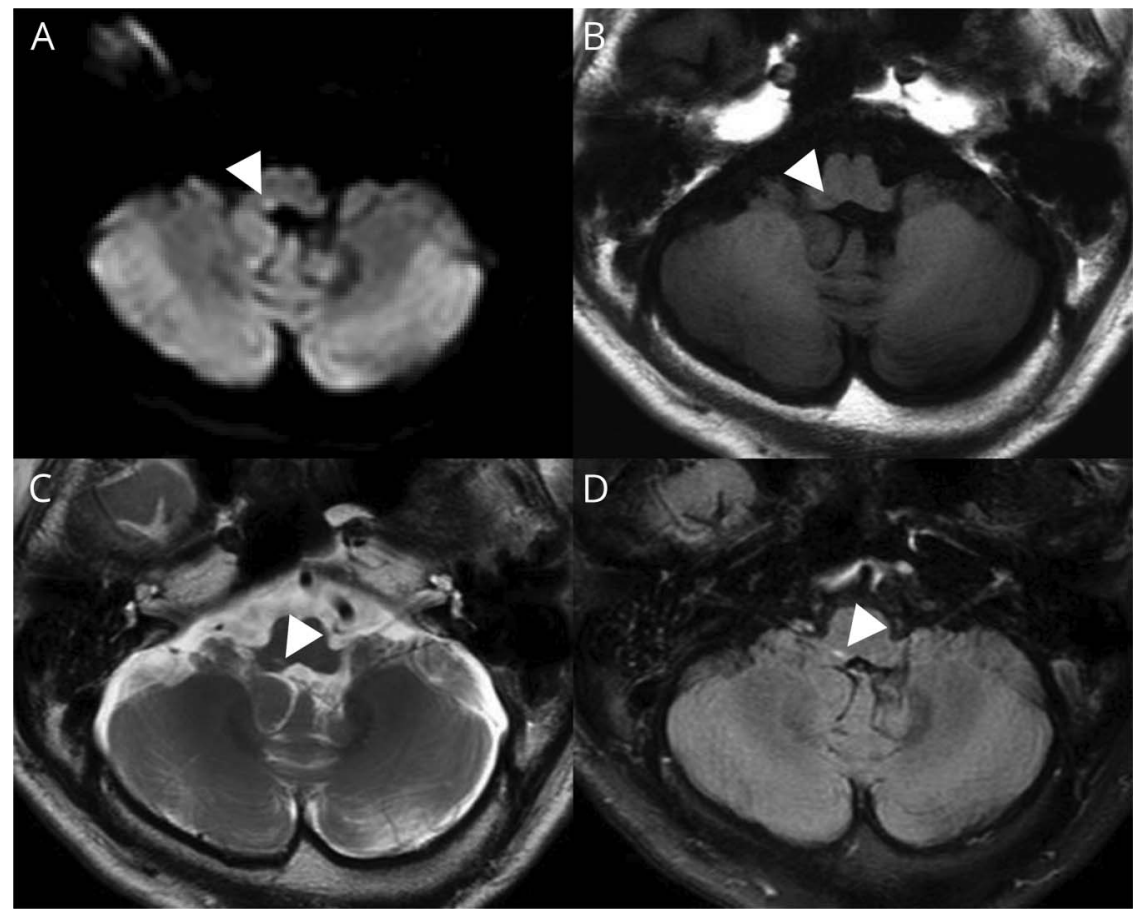

MRI axial diffusion-weighted imaging (A) shows small foci of diffusion restriction at the right dorsolateral of the medulla oblongata. This lesion shows as low signal intensity in axial T1-weighted image (B), high signal intensity in axial fluid-attenuated inversion recovery MRI and axial T2weighted image (C, D). It involves nucleus ambiguus and vagal nucleus.

A 76-year-old man presented with 4 days of hiccups. The patient denied dizziness, sensory changes, or weakness. Antiemetics, muscle relaxants, and antiepileptic treatments were ineffective. Seven days later, brain MRI with diffusion-weighted imaging revealed tiny ischemic lesions located in the nucleus ambiguous and vagal nucleus at right dorsolateral medulla (figure). The patient's hiccups lasted 2 weeks. Most hiccups with stroke are reported as one of the symptoms of lateral medullary syndrome. ${ }^{1}$ The mechanism of hiccup is imbalance and involuntary inspiration by destruction of the expiratory area in the medulla and is related in the nucleus ambiguus and dorsal motor nucleus of the vagus nucleus. ${ }^{2}$

\section{Study funding}

No targeted funding reported.

\section{Disclosure}

The author reports no disclosures relevant to the manuscript. Go to Neurology.org/ $\mathrm{N}$ for full disclosures.

\section{References}

1. Park MH, Kim BJ, Koh SB, Park MK, Park KW, Lee DH. Lesional location of lateral medullary infarction presenting hiccups (singultus). J Neurol Neurosurg Psychiatry 2005;76:95-98.

2. Currier RD, Giles CL, Dejong RN. Some comments on Wallenberg's lateral medullary syndrome. Neurology 1961;11:778-791.

\section{MORE ONLINE}

\section{$\rightarrow$ Teaching slides}

links.lww.com/WNL/

A947

From the Department of Neurology, Inje University College of Medicine, Busan Paik Hospital, Busan, Korea.

Go to Neurology.org/N for full disclosures. 


\title{
Neurology
}

\author{
Teaching NeuroImages: Isolated and persistent hiccup by tiny ischemia at dorsolateral \\ medulla \\ Jung Hwa Seo \\ Neurology 2019;93;e934 \\ DOI 10.1212/WNL.0000000000008008
}

This information is current as of August 26, 2019

\section{Updated Information \& Services}

References

Subspecialty Collections

Permissions \& Licensing

Reprints including high resolution figures, can be found at: http://n.neurology.org/content/93/9/e934.full

This article cites 2 articles, 2 of which you can access for free at: http://n.neurology.org/content/93/9/e934.full\#ref-list-1

This article, along with others on similar topics, appears in the following collection(s):

\section{All Cerebrovascular disease/Stroke}

http://n.neurology.org/cgi/collection/all_cerebrovascular_disease_strok

All Clinical Neurology

http://n.neurology.org/cgi/collection/all_clinical_neurology

DWI

http://n.neurology.org/cgi/collection/dwi

MRI

http://n.neurology.org/cgi/collection/mri

Information about reproducing this article in parts (figures,tables) or in its entirety can be found online at:

http://www.neurology.org/about/about_the_journal\#permissions

Information about ordering reprints can be found online:

http://n.neurology.org/subscribers/advertise

Neurology ${ }^{\circledR}$ is the official journal of the American Academy of Neurology. Published continuously since 1951, it is now a weekly with 48 issues per year. Copyright (O 2019 American Academy of Neurology. All rights reserved. Print ISSN: 0028-3878. Online ISSN: 1526-632X.

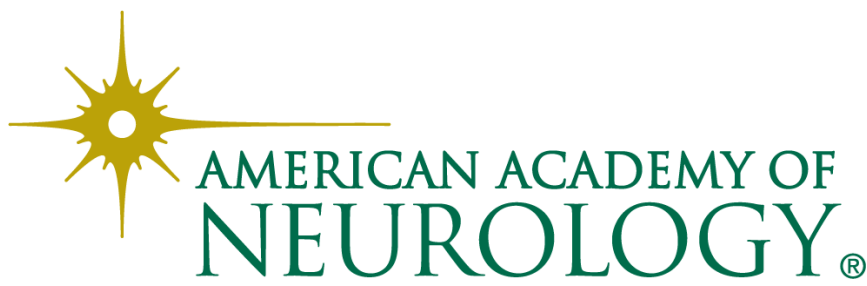

